\title{
Modern and Little Ice Age glaciers in "humid" and "arid" areas of the Tien Shan, Central Asia: two different patterns of fluctuation
}

\author{
O. S. SAvosKuL \\ Institute of Geography, Russian Academy of Sciences, Staromonetny 29, Moscow 109017, Russia
}

\begin{abstract}
Patterns of retreat from maximum Little Ice Age (LIA) to present limits are studied at 20 glaciers in the relatively humid northwestern front ranges and arid inner areas of the Tien Shan, Central Asia. The depression of equilibrium-line altitudes has been calculated using several approaches. Data on changes of elevation ranges, glacier length and area are used to compare the patterns of glacier fluctuation. It is found that the large LIA glaciers in the warm and humid northwestern frontal ranges were 1.5-1.9 times larger in area than the modern glaciers; and the LIA glaciers in cold and arid inner parts of the Tien Shan were only 1.03-1.07 times larger. The changes in terminus-to-headwall elevation ranges are about $1.3-1.6$ and $1.02-1.10$, respectively. The largest LIA glaciers were 1.4-1.9 times longer than modern glaciers in "humid" ranges and only 1.02-1.12 times longer in "arid" areas. The maximum equilibrium-line depressions are approximately 100 $200 \mathrm{~m}$ in "humid" areas and $20-50 \mathrm{~m}$ in "arid" areas. These results suggest that the glaciers in the "humid" areas are likely to be more variable than those in "arid" areas. The differences may be explained either by differences in the sensitivity of glaciers to climate change or by variability of climate signals from one area to another.
\end{abstract}

\section{INTRODUCTION}

The Tien Shan, a mountain system of subparallel ranges running mainly east-west, is located to the north of the Tibetan Plateau. The area of glaciation in the Tien Shan is $15416 \mathrm{~km}^{2}$, and the number of glaciers larger than $0.1 \mathrm{~km}^{2}$ is 15953 (Kuzmichenok, 1993). Due to the influence of Atlantic cyclones, the climate of the northwestern periphery of the Tien Shan is warmer and much more humid than that of the inner areas. The differences in climate and topography provide different conditions for glaciation in the marginal and inner parts of the Tien Shan. At present, the area of an average glacier in the western and northern Tien Shan is $0.47-0.87 \mathrm{~km}^{2}$, and $0.75-1.73 \mathrm{~km}^{2}$ in the central and inner Tien Shan (Kuzmichenok, 1993), but the size fluctuated throughout the Little Ice Age (LIA), the last major episode of the late-Holocene glacier advances that occurred in the current millennium (Porter, 1986).

The LIA glacier fluctuations have been studied and documented by a number of authors (Serebryanyy and others, 1988; Chen Ji-yang, 1989; Solomina, 1990; Kotlyakov and others, 1991; Serebryanyy, 1992). Recently, Savoskul and Solomina (1996) published a paper in which the late-Holocene glacier positions of 23 glaciers in the northwestern marginal ranges and inner parts of the Tien Shan were mapped in detail and dated by lichenometry and the ${ }^{14} \mathrm{C}$ method. According to these data, the most prominent LIA advances occurred about 500-600, 250-300 and 150200 years ago.

Savoskul and Solomina (1996) provide evidence that the pattern of glacial variations shows considerable differences between the marginal and inner ranges: at the time of the maximum advances of the Little Ice Age, equilibrium-line altitudes (ELAs) as calculated by the method of median elevation of glaciers were $50-200 \mathrm{~m}$ lower than today in the northwestern ranges and only $20-40 \mathrm{~m}$ lower in the inner areas. They explained the different variability of glaciers by regional changes in precipitation: during the late Holocene it seems to have become more humid in the northwestern periphery, compared to the mid-Holocene and present, while the climate in the inner areas grew drier.

In this paper, we use several approaches to calculate the ELA, and introduce some other criteria to compare the patterns of LIA-to-present glacier fluctuations in the relatively humid frontal and arid inner ranges of the Tien Shan. Altogether 20 glaciers are considered; 19 glaciers were considered by Savoskul and Solomina (1996) and one was dated and mapped subsequently (Savoskul, in press).

\section{STUDY AREA}

Formed during the Alpine orogeny, the Tien Shan mountain system includes a number of subparallel ranges mainly running east-west between $70-85^{\circ} \mathrm{E}$ and $40-44^{\circ} \mathrm{N}$ (Fig. 1). These could be divided into western, northern, central, inner (or southern) and eastern (Chinese) Tien Shan. The valley topography and climate of the northwestern frontal areas differ considerably from those in the inner part of the Tien Shan. The valleys in the marginal ranges of the northern and western Tien Shan are steep and narrow. The inner Tien Shan is an uplifted peneplain with gently sloping, wide valleys. The central Tien Shan, which experienced the highest uplift, is characterized by significant erosion, deep, wide valleys and the highest altitudes (Peak Pobedy $7439 \mathrm{~m}$, 


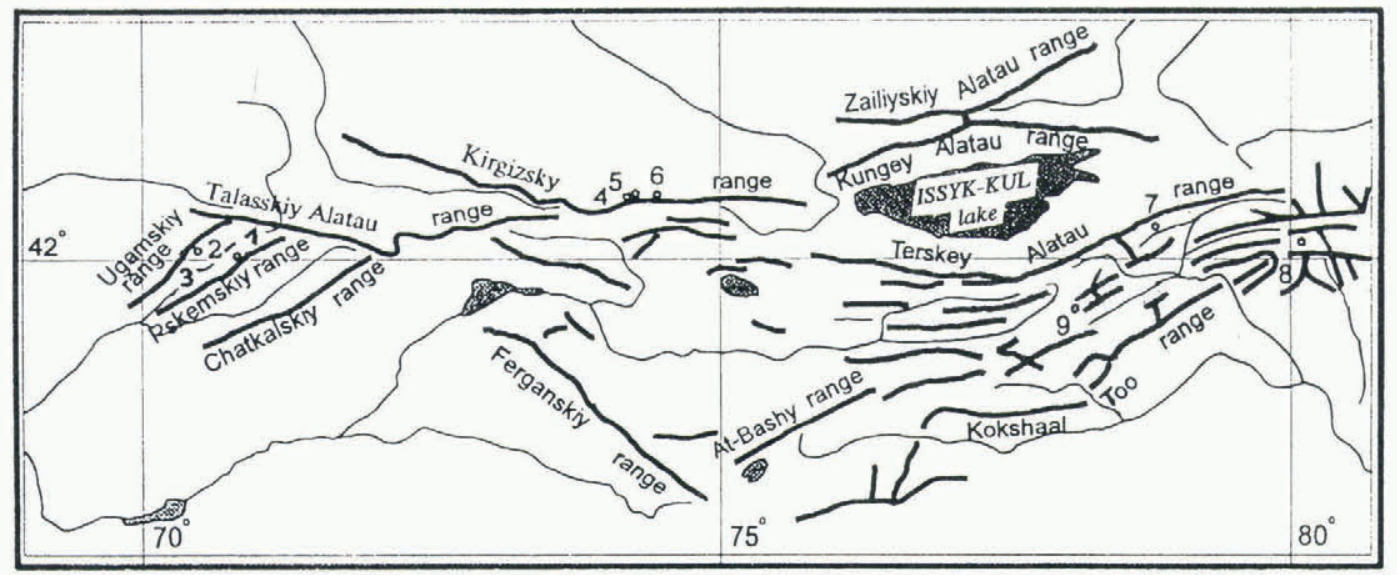

Fig. 1. Orographical scheme of the Tien Shan. Western Tien Shan: Talasskiy, Ugamskiy, Pskemskiy, Chatkalskiy, Ferganskiy ranges; northern Tien Shan: Kirgizskiy, Zailiyskiy, Kungey Alatau and northern slope of Terskey Alatau ranges; central Tien Shan: Khan-Tengry massif and the parts of Terskey Alatau and Kokshaal Too ranges east of $78^{\circ}$ E; inner Tien Shan: area northeast of Ferganskiy range, north of Kokshaal Too range and south of Terskey Alatau range. Numbers show locations of studied sites.

Khan-Tengry $6995 \mathrm{~m}$ ), while elsewhere in the mountains few summits rise above $5 \mathrm{~km}$. The western and northern Tien Shan has a warmer, more humid climate than do the inner areas.

\section{STUDY SITES}

Nine sites were selected in the western, northern, inner and central Tien Shan in order to allow a comparison of glacial behavior in the most humid and the most arid areas of the Tien Shan (Fig. 1). The local climate of the sites is characterized by the values of mean annual temperature and precipitation from the nearest meteorological stations (Table 1). Glaciers at sites 1-3 are located in the western Tien Shan in the Ugamskiy, Pskemskiy and Maidantalskiy ranges. Because of their westernmost position they receive the largest amount of precipitation within the entire Tien Shan, up to $1500 \mathrm{~mm}$ year ${ }^{-1}$. Sites 4-6 are located on the northern slope of the Kirgizskiy range, northern Tien Shan, where annual precipitation is $600-800 \mathrm{~mm}^{-1}$. Sites $^{-1}$ and 8 , central Tien Shan, on the southern slope of the Terskey Alatau range and the Khan-Tengry massif, are protected by frontal ranges from the penetration of humid air masses, as is site 9 in the Ak-Shiyrak massif, inner Tien Shan, and their average annual precipitation varies from 310 to 430 mm year $^{-1}$. Estimated mean annual temperature at an average elevation of lower glacier limits varies from about $-3^{\circ}$ to $-8^{\circ} \mathrm{C}$ from the west (sites $\left.1-6\right)$ to the east (sites 7-9). Most of the precipitation in the western Tien Shan falls in winter, while elsewhere it falls in summer.

The glaciers under study, taken as representative for their surroundings, are of various sizes and types (Table 2). Barkrak Sredniy glacier and Turpakbel Nizhniy glacier are under international environmental monitoring (Haeberli and Hoelzle, 1993). Recent studies in the inner and central Tien Shan show that the four glaciers selected here are representative for the area (Serebryanyy and others, 1988; Solomina, 1990; Kotlyakov and others, 1991). The maximum extent of the LIA glaciers has been reconstructed from terminal moraines and rock glaciers, dated by lichenometry and the ${ }^{14} \mathrm{C}$ method (Savoskul and Solomina, 1996; Savoskul, in press).

\section{GRITERIA USED TO GOMPARE PATTERNS OF GLACIER RETREAT}

The first criterion used to illustrate changes in glaciation is the depression of the equilibrium-line altitude (dELA). The difference between past and present ELAs is one of the most common indices traditionally used to characterize glacier fluctuations (Finsterwalder, 1953; Flint, 1971; Porter, 1975; Matthews, 1976; Oerlemans, 1989). There exist a number of

Table 1. Selected data from meteorological stations

\begin{tabular}{|c|c|c|c|c|c|c|}
\hline$M S$ & Alt & Lat & Long & $A P$ & $A T$ & ro \\
\hline & ma.s.l. & $\mathrm{N}$ & $\mathrm{E}$ & $\mathrm{mm}$ & ${ }^{\circ} \mathrm{C}$ & \\
\hline Pskem & 1400 & $41^{\circ} 49^{\prime}$ & $70^{\circ} 28^{\prime}$ & 833.7 & +9.2 & $1937-93$ \\
\hline Oigaing & 2200 & $42^{\circ} 05^{\prime}$ & $71^{\circ} 10^{\prime}$ & 779.5 & +2.2 & $1989-93$ \\
\hline Ala-Archa & 2945 & $42^{\circ} 29^{\prime}$ & $74^{\circ} 28^{\prime}$ & 713 & -0.7 & $1960-73$ \\
\hline Kuilu & 2800 & $42^{\circ} 12^{\prime}$ & $79^{\circ} 01^{\prime}$ & 312 & -2.2 & $1961-87$ \\
\hline Sary-Jas & 1956 & $42^{\circ} 55^{\prime}$ & $79^{\circ} 36^{\prime}$ & 405 & +2.3 & $1940-87$ \\
\hline Daxigou" & 3588 & $43^{\circ} 07^{\prime}$ & $86^{\circ} 50^{\prime}$ & 430 & -5.4 & ? \\
\hline
\end{tabular}

MS, meteorological station; Alt, altitude; Lat, latitude; Long, longitude; AP, annual precipitation; AT, annual temperature; YO, years of observation.

* According to Chen Ji-yang (1989). 
Table 2. Glacier characteristics

\begin{tabular}{|c|c|c|c|c|c|c|c|c|c|c|c|c|c|}
\hline Sile & V & $I$ & $P$ & No & Name & $A s p$ & Type & $\begin{array}{c}A \\
\mathrm{~km}^{2}\end{array}$ & $\begin{array}{c}L \\
\mathrm{~km}\end{array}$ & $\begin{array}{c}U L \\
\text { ma.s.l. }\end{array}$ & $\begin{array}{c}L L \\
\text { m a.s.l. }\end{array}$ & $\begin{array}{l}L L(A) \\
\text { ma.s.l. }\end{array}$ & $\begin{array}{l}L I A L L \\
\text { m a.s.l. }\end{array}$ \\
\hline \multirow[t]{2}{*}{1} & 14 & 1 & 1 & 54 & Barkrak Sredniy & W & VCo & 2.4 & 2.8 & 4100 & 3540 & - & 3180 \\
\hline & 14 & 1 & 1 & 55 & Barkrak Praviy & $\mathrm{S}$ & $\mathrm{CqV}$ & 1.4 & 2.0 & 4200 & 3550 & - & 3330 \\
\hline 2 & 14 & 1 & 1 & 196 & Turpakbel Nizhniy & $\mathrm{E}$ & $\mathrm{NCq}$ & 1.5 & 1.6 & 3650 & 3200 & 3260 & 3000 \\
\hline 3 & 14 & 1 & 1 & 116 & Tekesh & $\mathrm{SE}$ & $\mathrm{CqV}$ & 1.6 & 3.2 & 4100 & 3050 & 3130 & 3000 \\
\hline \multirow[t]{8}{*}{4} & 14 & 2 & 2 & 238 & & SE & $\mathrm{Cq}$ & 0.1 & 0.6 & 4100 & 3680 & 3680 & 3470 \\
\hline & 14 & 2 & 2 & 239 & & $\mathrm{NE}$ & HV & 0.8 & 1.2 & 4080 & 3480 & 3530 & 3470 \\
\hline & 14 & 2 & 2 & 240 & - & $\mathrm{E}$ & $\mathrm{Cq}$ & 0.1 & 0.5 & 3950 & 3600 & 3600 & 3450 \\
\hline & 14 & 2 & 2 & 241 & - & $\mathrm{E}$ & $\mathrm{Cq}$ & 1.9 & 1.8 & 4090 & 3520 & 3540 & 3450 \\
\hline & 14 & 2 & 2 & 242 & - & $\mathrm{NE}$ & V & 0.9 & 1.8 & 4080 & 3380 & 3380 & 3250 \\
\hline & 14 & 2 & 2 & 243 & & $\mathrm{~N}$ & V & 1.4 & 2.3 & 4080 & 3440 & 3440 & 3250 \\
\hline & 14 & 2 & 2 & 244 & - & $\mathrm{NW}$ & $\mathrm{V}$ & 2.4 & 2.5 & 4200 & 3440 & 3440 & 3250 \\
\hline & 14 & 2 & 2 & 245 & - & w & V & 1.1 & 1.9 & 4240 & 3440 & 3440 & 3250 \\
\hline 5 & 14 & 2 & 2 & $255-256$ & Aksay & SW & VCo & 8.5 & 6.4 & 4870 & 3220 & 3320 & 3000 \\
\hline \multirow[t]{3}{*}{6} & 14 & 2 & 2 & 310 & Chokoltor & $\mathrm{N}$ & V & 0.2 & 0.8 & 4100 & 3800 & 3800 & 3720 \\
\hline & 14 & 2 & 2 & $311-312$ & - & $\mathrm{N}$ & VCo & 7.3 & 3.5 & 4600 & 3750 & 3750 & 3350 \\
\hline & 14 & 2 & 2 & 316 & & $\mathrm{~N}$ & $\mathrm{Cq}$ & 0.1 & 0.8 & 3900 & 3720 & - & 3630 \\
\hline \multirow[t]{2}{*}{7} & 14 & 2 & 7 & $317-319$ & Kolpakovskiy & $\mathrm{S}$ & VCo & 19.6 & 10.0 & 4750 & 3660 & 3720 & 3600 \\
\hline & 14 & 2 & 7 & 321 & & $\mathrm{~s}$ & $\mathrm{~V}$ & 12.7 & 6.1 & 4720 & 3980 & 3850 & 3760 \\
\hline 8 & 14 & 2 & 8 & 44 & Semenov & W & $\mathrm{GrV}$ & 34.2 & 18.4 & 5820 & 3460 & 3460 & 3420 \\
\hline 9 & 14 & 1 & 5 & 368 & Petrov & NW & $\mathrm{GrV}$ & 69.8 & 11.3 & 4900 & 3730 & 3730 & 3700 \\
\hline
\end{tabular}

Data given according to Vinogradov (1976): V, volume; I, issue; P, part; No, number of glacier; Asp, aspect; N, north; E, east; S, south; W, west; Type: N, niche, $\mathrm{Cq}$, cirque, V, valley, NCq, niche cirque, $\mathrm{CqV}$, cirque valley, $\mathrm{HV}$, hanging valley, VCo, two coalescing valley glaciers, GrV, more than two coalescing valley glaciers; A, area; L, length; UL, upper limit; LL, lower limit. Data given by authors: LL(A), lower glacier limit measured by altimeter; LIA LL, Little Ice Age lower limit.

different approaches to the calculation of dELA (Brückner, 1887; Richter, 1888; Kurowski, 1896; Finsterwalder, 1953; Meier and Post, 1962; Andrews, 1975; Porter, 1975; Meierding, 1982; Sutherland, 1984; Hawkins, 1985; Kuhle, 1988; Murray and Locke, 1989; Nesje, 1992; Klimaszewski, 1993; Torsnes and others, 1993; Seltzer, 1994; Aa, 1996). Recent reviews have shown that the results of ELA calculation vary considerably depending on the method used (Meierding, 1982; Torsnes and others, 1993; Aa, 1996), so the choice of the most appropriate method for each particular area or glacier needs special investigation.

In this paper, dELA is calculated using the following

Table 3. Little Ice Age characteristics

\begin{tabular}{|c|c|c|c|c|c|c|c|c|c|c|c|c|}
\hline \multirow[t]{3}{*}{ Site } & \multirow[t]{3}{*}{ V } & \multirow[t]{3}{*}{$I$} & \multirow[t]{3}{*}{$P$} & \multirow[t]{3}{*}{ No } & \multirow[t]{3}{*}{ Name } & & $d E I$ & & & \multirow[t]{3}{*}{$d E R$} & $d L$ & \multirow[t]{3}{*}{$d A$} \\
\hline & & & & & & $M E G$ & $T H A R^{*}$ & $A A R^{+}$ & MALM & & & \\
\hline & & & & & & $\mathrm{m}$ & $\mathrm{m}$ & $\mathrm{m}$ & $\mathrm{m}$ & & & \\
\hline
\end{tabular}

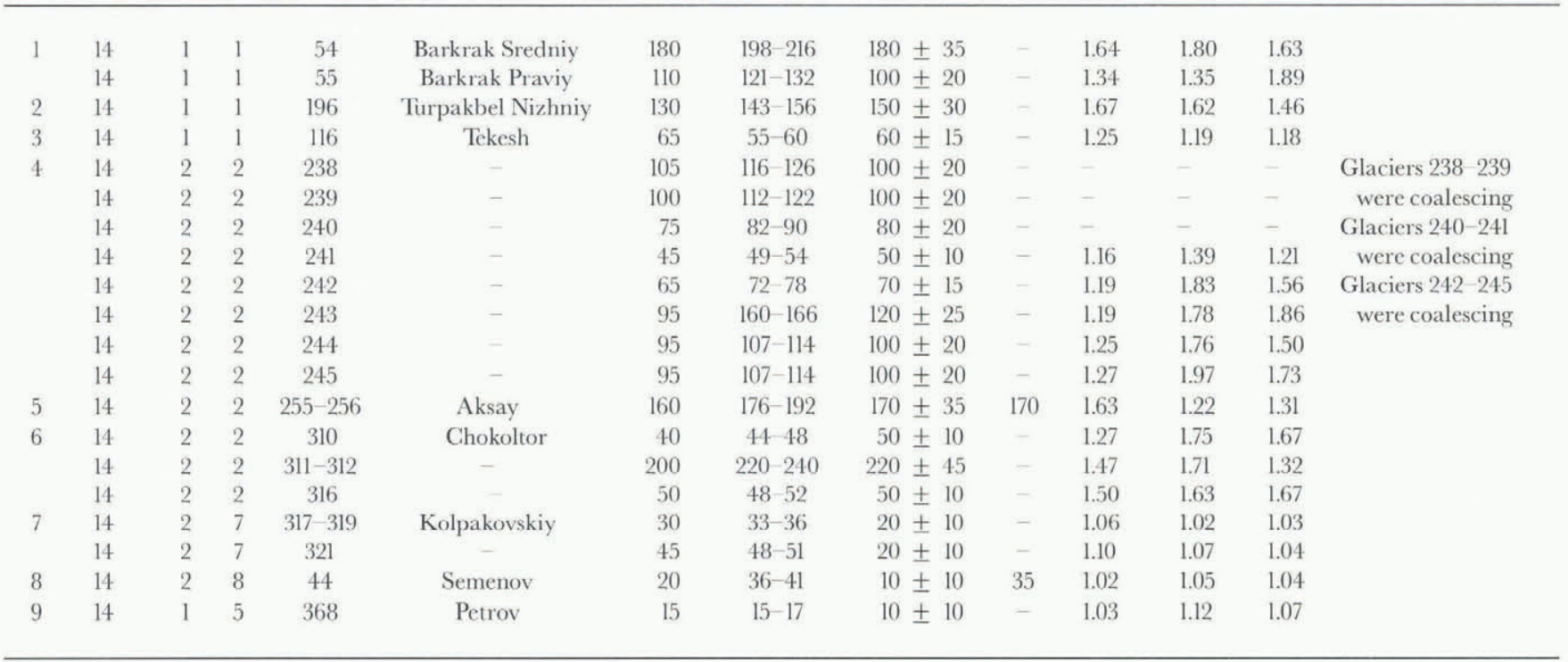


approaches, recently reviewed and evaluated by Nesje (1992), Torsnes and others (1993) and Aa (1996):

(1) Median elevation of glaciers (MEG) (Manley, 1959).

(2 Toe-to-headwall altitude ratio (THAR) (Meierding, 1982). This approach was applied using ratios of $0.4-0.55$.

(3) AAR (Meier and Post, 1962). This approach was applied using topographical maps $(1: 100000,1968-72)$ and an AAR of $0.67 \pm 0.03$ (Dyurgerov, 1995).

(4) Maximum elevation of lateral moraines (MELM) (Andrews, 1975). This approach could not be applied to each glacier because of lack of data for some glaciers.

Apart from dELA, three other indices are introduced here to characterize LIA-to-present changes in glacier extent and configuration. These are:

(5) $d E R$ : elevation range of LIA glacier/elevation range of modern glacier.

(6) $d L$ : length of LIA glacier/length of modern glacier.

(7) $d A$ : area of LIA glacier/area of modern glacier.

Note that $\mathrm{dER}, \mathrm{dL}$ and $\mathrm{dA}$ are ratios, not differences, of the respective values.

For a group of glaciers that coalesced during the LIA, present altitudinal range is taken from the glacier that occupies the maximal altitudinal range, present length is taken from the longest glacier and present area is calculated as the sum of all glaciers in the group. Topographic maps of 1:100000 scale were used to determine the changes in
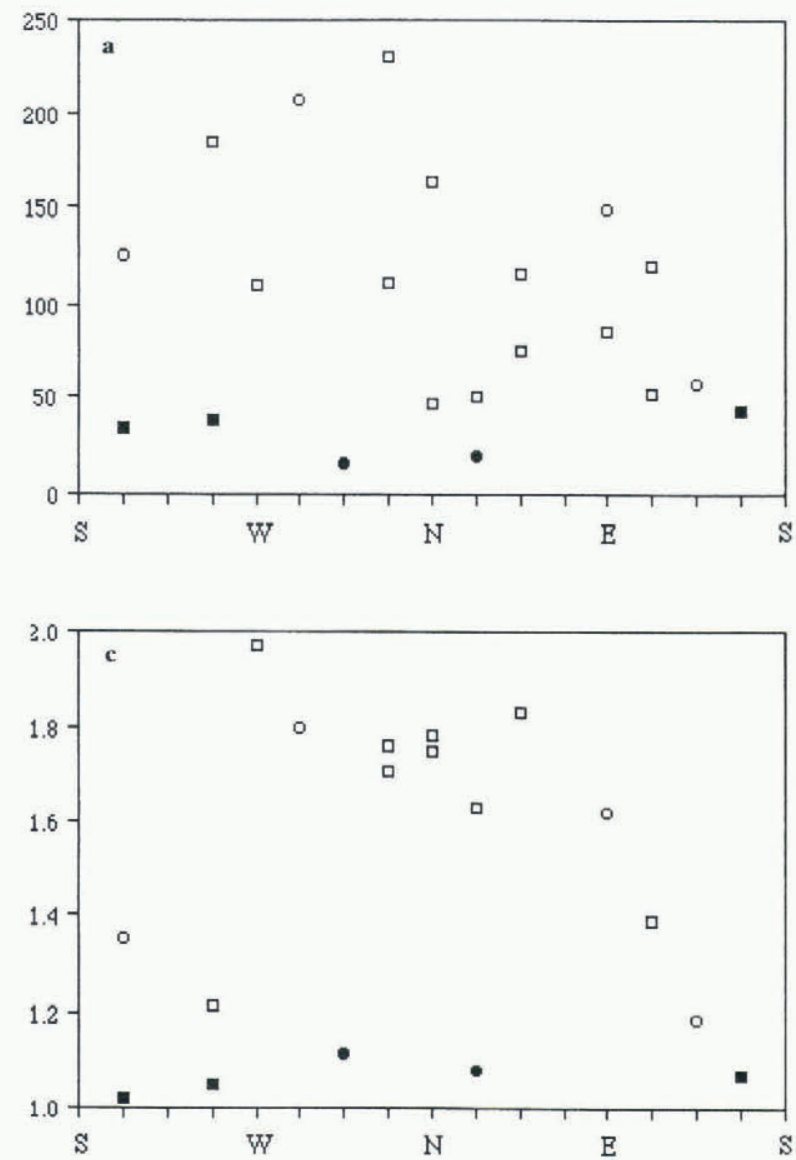

glacier length and area. For sites 5, 7 and 9, aerial photographs were available with an approximate scale of 1:25000. The lower glacier limits and moraine elevations were measured by altimeter with an accuracy of $\pm 10 \mathrm{~m}$.

\section{RESULTS}

The results of the calculations summarized in Table 3 show that in the western Tien Shan (sites 1-3) the dELA estimates obtained by the MEG approach vary from 65 to $180 \mathrm{~m}$; using the THAR gives values from $80-85$ to $215-235 \mathrm{~m}$; and the AAR method gives estimates from $80 \pm 20$ to $180 \pm 35 \mathrm{~m}$. In the northern Tien Shan (sites 4-6) those methods give estimates of $40-200 \mathrm{~m}, 50$ to $220-240 \mathrm{~m}$ and $50 \pm 10$ to $220 \pm 45 \mathrm{~m}$, respectively. The differences in the ELA estimates can be attributed to differences in glacier size, morphology, aspect and valley topography. The dELA estimates for the central and inner Tien Shan (sites 7-9) vary within a much smaller range: $15-45 \mathrm{~m}$ (MEG); 15 to $50 \mathrm{~m}$ (THAR); and $10 \pm 10$ to $20 \pm 10 \mathrm{~m}$ (AAR).

The calculated values of $\mathrm{dER}, \mathrm{dL}$ and $\mathrm{dA}$ show that in the western and northern Tien Shan the elevation ranges, length and area of the LIA glaciers were about 20-100\% larger than those of modern glaciers, while in the central and inner Tien Shan the fluctuations of those characteristics were within a range of $2-12 \%$. These differences, as well as differences in dELA given by all the methods of estimation, show that there exist two different patterns of LIA-topresent glacier fluctuations, which can more likely be ex-
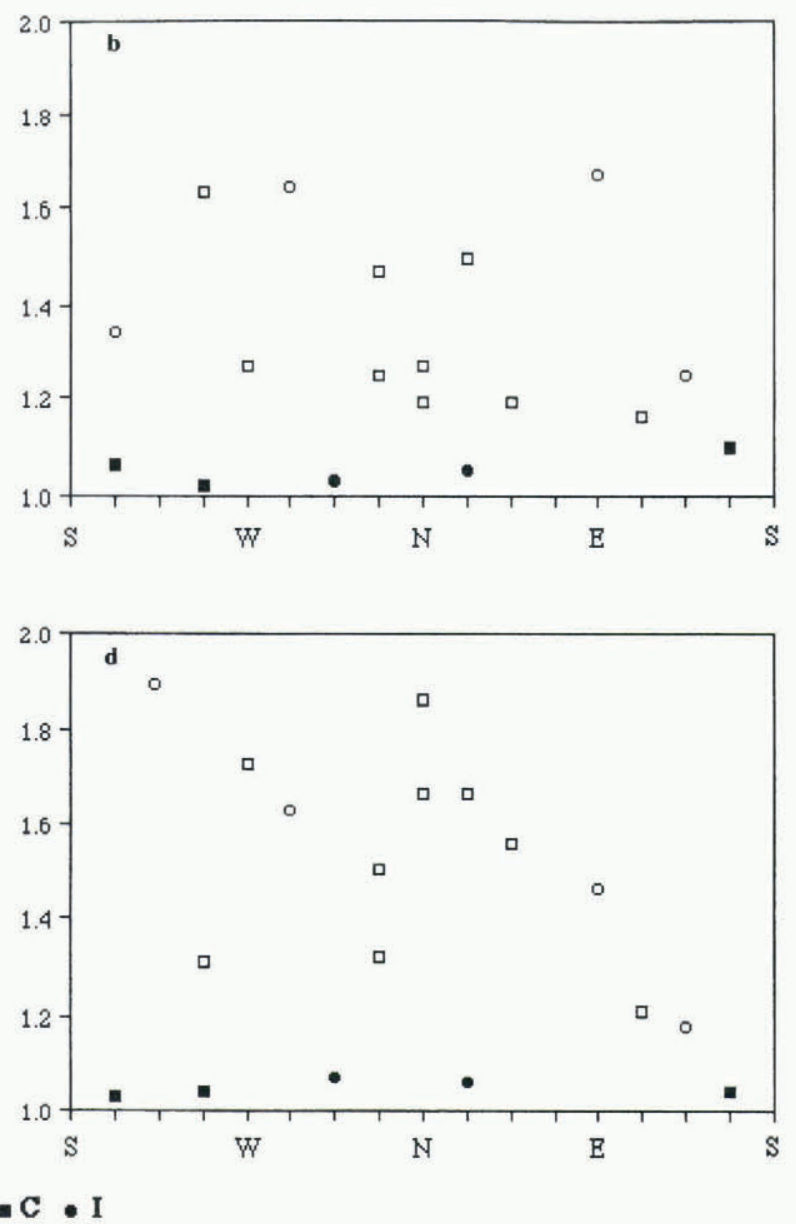

Fig. 2. Characteristics of LIA glaciers. Horizontal axis: glacier aspect. Vertical axes: (a) dELA (THAR); (b) dER; (c) dL; (d) dA.W, western Tien Shan; $\mathcal{N}$, northern Tien Shan; C, central Tien Shan; I, inner Tien Shan. 
plained by regional factors than by any variations in valley topography and morphology or other local conditions.

\section{PATTERN OF GLACIER FLUCTUATIONS IN "HUMID"AREA OF THE TIEN SHAN}

Before considering the question of the accuracy of determination of dELA, it can be stated that all the methods give a wide range of dELA variations for glaciers in the western and northern Tien Shan, approximately from 40-60 to $180-240 \mathrm{~m}$. The changes of dER, dL and dA are very large as well. The data presented in Table 3 show that here the largest glaciers are the most variable; in particular the dELA estimation for nearly all the glaciers larger than $1 \mathrm{~km}^{2}$ exceeds $100 \mathrm{~m}$. In Figure 2, where dELA (THAR), dER, dL and dA are plotted against glacier aspect, it appears that the glaciers exposed more to the north than to the south are likely to be more variable: this was shown, for instance, for the Atlantic rock glaciers by Humlum (1988). The influence of glacier topography and morphology on their variability is as follows: the LIA glaciers with big accumulation area and narrow tongues of valley type seem to have undergone the most drastic changes and altered into the modern glaciers of valley or cirque type lying at present above LIA cirque thresholds (Savoskul and Solomina, 1996); the influence of this factor on modern glaciers is discussed in detail by Oerlemans (1989). By contrast, LIA glaciers of the cirque type have not, as a rule, undergone any considerable change in dimensions and, consequently, type. Hence, the most variable in the "humid" areas of the Tien Shan are large, north-exposed valley glaciers, which should be considered the most representative for the northwestern periphery. The dELA of these glaciers varies roughly from 100 to $200 \mathrm{~m}$, the range of $\mathrm{dER}$ is about $1.30-1.60$, and those of $\mathrm{dL}$ and $\mathrm{dA}$ are about $1.40-1.90$ and $1.50-1.90$, respectively.

\section{PATTERN OF GLAGIER FLUGTUATIONS IN "ARID"AREAS}

In the central and inner Tien Shan only four large glaciers were investigated, so there is no opportunity to consider the influence of local factors on the variability of glaciers, but the glaciers investigated are typical of this area. The dELA of these large glaciers according to all the estimates does not exceed $15-60 \mathrm{~m}$, which is very low in comparison to the glaciers in the frontal ranges. The variations of dER, dL and $\mathrm{dA}$ are even more illustrative, the range being only $1.02-1.12$. This means that the retreat of those glaciers from the maximum LIA limit related to their modern dimensions was modest and they have not changed type. The large glaciers in the cold, dry inner areas of the Tien Shan seem to be more stable than those in the warm, humid northwestern frontal areas, especially with respect to their areal dimensions and ELA.

There are two probable explanations for this phenomenon. The first concerns qualities specific to given glaciers. The smaller, more active glaciers of the frontal ranges are probably more sensitive to climate variations than the large, stable glaciers of the inner ranges. In this case, climate variations seem more likely to result in fluctuations of the area of glaciation, while in humid areas they cause a lowering of the glacier surface (Liu Chaohai and Han Tianding, 1992; Dyurgerov, 1995). In other words, it could be that in both areas climate variations of similar magnitudes resulted in similar trends in long-term changes of mass balance. Another explanation we referred to earlier (Savoskul and Solomina, 1996) is that the climate signals were of different magnitude in the frontal and inner areas of the Tien Shan, i.e. that during the cooling intervals of the late Holocene the precipitation increased in the frontal areas and decreased in the inner areas as compared to warmer intervals, and thus the long-term changes in mass balance were also different.

\section{ACGURAGY OF ESTIMATION OF MODERN AND LIA GLACIER CHARACTERISTICS}

The accuracy of determination of ELAs of both past and modern glaciers is a much-discussed question, and there exist a number of different approaches to the calculation of dELA, as was shown in an earlier section of this paper. An indicator of the accuracy of estimation of modern ELAs was provided by data from field measurements on Barkrak Sredniy and Barkrak Praviy glaciers (Vinogradov, 1976) in the western Tien Shan. The best results are obtained by the AAR and the THAR method, using an AAR of $0.67 \pm 3$ and THAR of $0.40-0.45$, whereas the MEG method overestimates the ELA. In the northern Tien Shan, modern ELA is derived from aerial photographs for Aksay glacier $(3770 \mathrm{~m})$, where the AAR method gives the most appropriate results. In the central and inner Tien Shan, data on the modern ELAs of Kolpakovskiy and Petrov glaciers can be obtained from aerial photographs, and here the use of THAR of $0.45-0.50$ and $0.5-0.55$, respectively, was most successful.

According to these data, in northwestern areas of the Tien Shan the MEG method gives lower values of dELA than the THAR and AAR methods. In the inner areas the THAR method is likely to provide the most reliable results, while AAR and MEG methods fail to take into account variations in glacier morphology and topography. Apparently, the AAR method is not ideal for large, coalescing valley glaciers of rather complicated morphology such as the Semenov and Petrov glaciers. One reason for the very low accuracy of the AAR method in these circumstances could be the difficulty of determining the surface lowering, which should be rather significant for large glaciers. For instance, the elevation of the LIA lateral moraines above the surface of the modern Petrov glacier provides evidence for a surface lowering of $50 \mathrm{~m}$, and there is a surface lowering of not less than $70 \mathrm{~m}$ for Semenov glacier. The results obtained by the MEG and AAR methods are comparable, first, for small, geometrically regular glaciers in frontal areas, as in the Atlantic region (Torsnes and others, 1993; Aa, 1996), and, secondly, for the large glaciers in inner areas, where both methods are of very low accuracy, and therefore the THAR method seems to provide the most reliable results.

The accuracy of the determination of $\mathrm{dER}, \mathrm{dL}$ and $\mathrm{dA}$ apparently depends on the scale and quality of the maps used, and on the accuracy of elevation measurements (see above). However, there are other sources of mistakes. First is the accuracy of the age estimation of glacier deposits used to find out the LIA glacier limits, which is discussed in detail in Savoskul and Solomina (1996). The second critical point is the use of rock glaciers for reconstruction of LIA glacier limits at site 1 (glacier Barkrak Praviy) and site 6 (glacier Nos. 311-312). It is very probable that the length and area 
are overestimated, because of the unknown rates of rock glacier movement, though taking into account the gentle sloping of the valley bottoms they should not be very high.

\section{SUMMARY AND CONCLUSIONS}

During the LIA maximum advance, differences between the "humid" and "arid" areas in terms of the dimensions of the largest glaciers were smaller than today. Whereas the area of the large LIA glaciers in the warm, humid northwestern frontal ranges was 1.5-1.9 times larger than that of the modern glaciers, the area of the LIA glaciers in the cold, arid inner parts of the Tien Shan was only 1.03-1.07 times larger than at present. The changes in elevation ranges are about $1.3-1.6$ and $1.02-1.10$, respectively. The largest LIA glaciers were 1.4-1.9 times longer than modern glaciers in "humid" ranges, and only 1.02-1.12 times longer in "arid" areas. The maximum dELA is approximately $100-200 \mathrm{~m}$ in "humid" areas, and 20-50 $\mathrm{m}$ in "arid" areas.

The most variable glaciers in the "humid" areas of the Tien Shan are large, north-exposed valley glaciers, which should be considered the most representative of the northwestern periphery. Smaller cirque glaciers and glaciers exposed more to the south in general experienced fluctuations of smaller magnitude.

Large glaciers in the "arid" areas were very stable throughout the LIA; the ELA, elevation range, length and area of these glaciers have undergone fluctuations of small magnitude, though the lowering of the glacier surface could be very significant, up to $50-70 \mathrm{~m}$.

Differences in the pattern of glacier changes may be explained either by differences in the sensitivity of glaciers to climate change or by differences in the magnitude of climate signals causing the glacier fluctuations.

\section{ACKNOWLEDGEMENTS}

This study was conducted in 1993 as a part of the author's $\mathrm{Ph} . \mathrm{D}$. thesis under the supervision of Academician V. M. Kotlyakov and Dr O. N. Solomina, Institute of Geography, Russian Academy of Sciences, who are gratefully acknowledged. The author is very grateful also to Dr A.V. Orlov for his support of this work.

\section{REFERENCES}

Aa, A. R. 1996. Topographic control of equilibrium-line altitude depression on reconstructed "Little Ice Age"glaciers, Grovabreen, western Norway. Holocene, 6(1), 82-89.

Andrews, J.T. 1975. Glacial systems; an approach to glaciers and their environments. North Scituate, MA, Duxbury Press.

Brückner, E. 1887. Die Höhe der Schneelinie und ihre Bestimmung. Meteorol. Z, 4(1), 31-32.

Chen Ji-yang. 1989. Preliminary researches on lichenometric chronology of Holocene glacial fluctuations and on other topics in the headwater of Urumqi River, Tian-Shan Mountains. Sci. China, Ser. B, 32(12), 14871500.

Dyurgerov, M.B., ed. 1995. Oledeneniya Tyan'-Shanya [Tien Shan glaciers]. Moscow, Vsesoyuznyy Institut Nauchnoy i Tekhnicheskoy Informatsii (VINITI).

Finsterwalder, R. 1953. Die zahlenmässige Erfassung des Gletscherrückgangs an Ostalpengletschern. Z Gletscherkd. Glazialgeol., 2(2), 189-239.

Flint, R. F. 1971. Glacial and Quaternary geology. New York, etc., JohnWiley and Sons.
Haeberli, W. and M. Hoelzle, eds. 1993. Fluctuations of glaciers 1985-1990 (Vol. VI). Wallingford, Oxon., IAHS Press; Nairobi, UNEP; Paris, Unesco.

Hawkins, F. F. 1985. Equilibrium-line altitudes and paleoenvironment in the Merchants Bay area, Baffin Island, N.W.T., Canada. 7. Glaciol., $31(109), 205-213$.

Humlum, O. 1988. Rock glacier appearance level and rock glacier initiation line altitude: a methodological approach to the study of rock glaciers. Arct. Alp. Res., $20(2), 160-178$.

Klimaszewski, M. 1993. Conditions of the Pleistocene glaciation of mountainous regions. Z. Geomorphol., 37(1), 1-18.

Kotlyakov, V. M., L. R. Serebryannyy and O. N. Solomina. 1991. Climatic change and glacier fluctuation during the last 1,000 years in the southern mountains of the USSR. Mount. Res, Dev., 11 (1), 1-11.

Kuhle, M. 1988. Topography as a fundamental element of glacial systems a new approach to ELA calculation and typological classification of paleo- and recent glaciations. Geofournal, $17(4), 545-568$.

Kurowski, L. 1896. Die Höhe der Schneegrenze mit besonderer Berücksichtigung der Finsteraarhorn-Gruppe. Geographische Abhandlungen, Berlin Universität, 5(1), 119-160.

Kuzmichenok, V.A. 1993. Ledniki Tyan'-Shanya. Komp'yuternyy analiz kataloga [The glaciers of Tyan'-Shan'. Computerized analysis of the inventory]. Mater. Glyatsiol. Issled. 77, 29-41.

Liu Chaohai and Han Tianding. 1992. Relation between recent glacier variations and climate in the Tien Shan Mountains, central Asia. Ann. Glaciol., 16, 11-16.

Manley, G. 1959. The late-glacial climate of north-west England. Liverpool and Manchester Geological Journal, 2(2), 188-215.

Matthews, J. A. 1976. Little Ice Age paleotemperatures from high altitude tree growth in S. Norway. Nature, 264 (18), 1243-245.

Meier, M. F. and A. S. Post. 1962. Recent variations in mass net budgets of glaciers in western North America. International Association of Scientific Hydrology Publication 58 (Symposium at Obergurgl 1962 - Variations of the Regime of Existing Glaciers), $63-77$.

Meierding, T. C. 1982. Late Pleistocene glacial equilibrium-line altitudes in the Colorado Front Range: a comparison of methods. Quat. Res., 18(3), 289-310.

Murray, D. R. and W.W. Locke, III. 1989. Dynamics of the Late Pleistocene Big Timber Glacier, Crazy Mountains, Montana, U.S.A. 7. Glaciol., 35(120), 183-190.

Nesje, A. 1992. Topographical effects on the equilibrium-line altitude on glaciers. Geofournal, $27(4), 383-391$.

Oerlemans, J., ed. 1989. Glacier fluctuations and climatic change. Dordrecht, etc., Kluwer Academic Publishers.

Porter, S. C. 1975. Equilibrium-line altitudes of Late Quaternary glaciers in the Southern Alps, New Zealand. Quat. Res., 5(1), 27-47.

Porter, S. C. 1986. Pattern and forcing of Northern Hemisphere glacier variations during the last millennium. Quat. Res., 26(1), $27-48$.

Richter, E. 1888. Die Gletscher der Ostalpen. Stuttgart, J. Engelhorn.

Savoskul, O.S. In press. Lichenometric and ${ }^{14} \mathrm{C}$ evidence for the Late Holocene glacier variations in the Oigaing River basin, western Tian Shan, central Asia. Z. Gletscherkd. Glazialgeol.

Savoskul, O. S. and O. N. Solomina. 1996. Late-Holocene glacier variations in the frontal and inner ranges of Tian Shan, central Asia. Holocene, 6(1), 25-35.

Seltzer, G. O. 1994. Climatic interpretation of alpine snowline variations on millennial time scales. Quat. Res., 41 (2), 154-159.

Serebryannyy, L. R. 1992. Glaciodynamic features of the Little Ice Age in the Soviet Union. In Mikami, T., ed. International Symposium on the Little Ice Age Climate, 25-27 September, 1991, Tokyo. Proceedings. Tokyo, Tokyo Metropolitan University. Department of Geography, 87-94.

Serebryannyy, L. R., A. V. Orlov and O. N. Solomina. 1988. Moreny istochnik glyatsiologicheskoy informatsii [Moraines as a source of glacial information]. Moscow, Nauka.

Solomina, O. N. 1990. Kolebaniya lednikov Vnutrennego Tyan'-Shanya po likhenometricheskim dannym [Fluctuations of glaciers of interior Tyan'-Shan' from lichenometric data]. Mater. Glyatsiol. Issled. 68, 142-148.

Sutherland, D. J. 1984. Modern glacier characteristics as basis for inferring former climate with particular reference to the Loch Lomond stadial. Ouat. Sci. Rev., 3, 291-309.

Torsnes, I., N. Rye and A. Nesje. 1993. Modern and Little Ice Age equilibrium-line altitudes on outlet valley glaciers from Jostedals-breen, western Norway: an evaluation of different approaches to their calculation. Arct. Alp. Res., 25(2), 106-116.

Vinogradov, O. N., ed. 1976. Katalog lednikov SSSR [ Inventory of glaciers in the USSR ], 14. Leningrad, Gidrometeoizdat. 